\title{
The Effect of Self-Concept and Creativity on Professional Competence of Paud Teacher in Cakranegara Mataram
}

\author{
Siti Zaenab ${ }^{1}$, Dita Destarilin Rizky Indryani ${ }^{2}$ \\ ${ }^{12}$ Institut Agama Hindu Negeri Gde Pudja Mataram \\ ${ }^{1}$ chilasita68@gmail.com
}

\begin{abstract}
The purpose of this study was to determine: (1) the effect of self-concept on the professional competence of kindergarten teachers in Cakranegara District, NTB (2) the effect of creativity on the professional competence of PAUD teachers in Cakranegara District, NTB (3) the effect of self-concept and creativity together the same as the professional competence of PAUD teachers in Cakranegara District, NTB. By using quantitative methods, this research contains numbers obtained from data and then processed using statistics and then interpreted.
\end{abstract}

Keywords: Learning Media; Teaching and Learning Activities; Surrounding Environment

\section{Introduction}

School is one of the places intended to gain knowledge, this has become a system in formal education. The formal education system has interrelated components, each component must have benefits and influence for the continuity of teaching and learning activities. These components include committees, educators, curriculum, facilities, environment, and school principals which are expected to support the achievement of learning objectives in schools (outputs). The teacher is the most important component in teaching and learning activities, aiming to convey or distribute knowledge to students. Given the importance of the teacher's role, the teacher must be a role model. So that students are expected to see and imitate the figure of a very noble teacher.

Teachers are an important factor in improving the quality of education. Teaching is a profession that is highly respected by society. Because teachers are tasked with educating the nation's next generation towards quality human resources (Usman 2016:7). Teachers are not only tasked with delivering learning materials in formal education classes. But also carry out the mandate in educating students to have broad knowledge and noble character. To carry out this mandate, teachers must have high creativity (Khurohman, 2017). Teacher competence can be a trigger in teaching and learning activities from primary to secondary education levels. Teachers must be able to develop and grow potential talents in each student in teaching and learning activities. So that it can produce graduates who have high achievements, both academic and non-academic. If teachers develop the concept of quality teachers and always create new innovations, the competence of teachers in schools will work.

According to the United Nations Development Program's Human Development Report (HDR) (2018: 127-129), the Human Development Index (HDI) of 184 countries, Indonesia is ranked 124th with a total index of 0.617. While neighboring countries such as Brunei Darussalam ranked 33, Malaysia ranked 61, Thailand ranked 103, and the Philippines ranked 112. Weak human resource development in Indonesia is not only seen from the report above, but also data on the increase in unemployment. This is of course detrimental to Indonesia, where humans are the most important factor in global competition. If it does not have a qualified quality, it can be seen that education has not been able to fulfill its objectives. 
In the context of early childhood education, education can stimulate, make children comfortable in their environment, and familiarize children with good things consistently. Planting this context can develop various potentials in children if it is done from a young age (Rasyid, 2009:39-40). Kindergarten education should make the experience as pleasant and warm as that given to education in the family sphere, because they are the successors to their families and this nation. An important factor that dominates formal education in general is the teacher, because of the stigma on students that the teacher is a noble figure. In learning activities, the teacher is tasked with encouraging, assisting, and facilitating. This responsibility is used to see the process of child development (Slameto, 2003: 97).

Society in general has fully trusted teachers in fostering and educating children, this is a demand for teachers in meeting community expectations. Early childhood teachers are required to have a loving, kind, attractive, and energetic personality supported by mastery of psychology. The basics in the concept of education become a benchmark in the success of teachers (Suyanto, 2005: 12). In realizing the goals of national education, teachers are required to be professional and able to improve the quality of conventional education in Indonesia which is routine, mechanism, dynamic (Irmin\&Rochim, 2006:68).

In building competence, the teacher himself sees himself as very influential. This self-confidence can affect the attitudes, thoughts, moods of teachers, because teachers feel happy and satisfied with their profession. According to Manrihu (1992:94) a person's level of satisfaction can be obtained from the implementation of his self-concept. A bad selfconcept will make it difficult for teachers to carry out their profession if teachers cannot recognize their talents and potential. Conversely, if the teacher is able to recognize himself well, then this can support his life's happiness in achieving success.

Self-concept is very important in interacting. Because each individual will behave according to his self-concept. Humans have a better self-knowledge than other living things. Humans are able to observe every action in themselves in adjusting and accepting the influence of the surrounding environment (Azis, 2014).

In improving the quality of education in Indonesia, teachers are the spearhead in this effort. So that the government makes teachers a profession that is parallel to other professional professions. As a professional profession, teachers must master all abilities that can support teaching and learning activities. This ability includes the mastery of academic knowledge, skills, attitudes (Samani, 2006: 16). This ability becomes a tool in exploring, investigating, analyzing, thinking, paying attention in guiding students to find the best way to achieve their goals (Mulyasa, 2013: 26). So that it is expected to be able to produce graduate students who have good personality, this hope will not be realized if there are no professional teachers in conventional education.

Teachers must have professional competence. Competence is related to adding insight through mastery of broad and deep learning materials including mastery of scientific substance in a curriculum (Suprihatiningrum, 2014: 115). Professional teachers have competencies that can be seen in understanding the material in the field of study broadly and deeply, so that they can add to the knowledge and insight of teachers in accordance with the applicable curriculum. This includes the teacher's mastery of the development of science and technology. So that mastery becomes an obligation so that teaching and learning activities are in accordance with existing standards.

Competence of professional teachers must master certain disciplines as teaching materials, know information about student characteristics, philosophy and educational goals, learning methods used, mastery of technology used in learning, able to assess, design, lead the learning process (Suprihatiningrum, 2014: 119). Professional kindergarten teachers are evidence in the implementation of pedagogical competence. So they must adhere to the principles of early childhood education, which are happy, happy, satisfied, 
and give freedom to children in choosing games and learning that are tailored to their interests. Thus, the environment for teaching and learning activitiesit must be designed so that students are comfortable to carry out learning and playing activities according to their wishes.

In general, humans tend to set values when perceiving something. Individuals can consciously know the situation and their identity but the most important thing is to be aware of the good and bad of a situation so that they will know what kind of attitude will be taken to respond to the situation. Individual attitudes are related to the quality of selfconcept, both positive and negative. As humans, teachers also have a self-concept, to support their profession, teachers must have a positive self-concept and let go of a negative self-concept.

Research conducted by Judiani, S. (2011), shows that there is a significant positive influence on the ability of elementary school teachers in creativity and competence. In line with research conducted by Mullyanti (2008), with the results of research on the basic concepts of professional teachers and teacher performance. In this study, the competence of teachers on the success of learning fiqh.

Furthermore, according to Rusneli's research (2016), it shows that there is an influence between the leadership of the principal, the professional competence of the teacher, the influence of discipline in work on professional competence.

PAUD education and teaching in the Cakranegara sub-district of NTB is expected to be able to meet the educational standards set by the government, including facilities, curriculum, and learning processes. So that students can carry out learning activities comfortably and can achieve their goals. According to the results of a survey conducted on principals and 15 of 23 teachers in Cakranegara District, NTB, that teaching implementation is still far from what was expected. Professional teacher is a job that is required to have skills and creativity, but in fact in delivering material to PAUD children there is still no visible creative and innovative learning model so that children get bored easily, most teachers are less creative to prepare learning media every day. . The existence of teachers in the Mengwi sub-district is very low, there are still many teachers who cannot know themselves that sometimes teachers are often late for school, underestimate school administration, are less friendly to school residents and also the attitude of teachers in classroom learning. So that researchers are interested in researching the topic of the influence of self-concept and teacher creativity on furu professional competence in Cakranegara District, NTB.

Learning in primary to secondary education is driven by teacher competence. Where teachers have several competencies including pedagogic competence, personality competence, professional competence, and social competence. So every teacher can take advantage of his competence to grow the talents and potential of students in the learning process. The teacher is one of the dominating and important factors in learning activities in conventional education. Teacher quality is supported by self-concept. Self-concept is an important factor in the interaction between teachers and students. Because humans are living beings who are able to recognize and observe themselves in every action they take (Azis, 2014).

Humans have potential that can be developed through the process of thinking and then into ideas and ideas. This becomes a stimulus in bringing up new actions and creativity. Rogers (in Munandar 2012: 18) that creativity is a tendency to encourage selfpotential to develop. Clark Moustakis (in Munandar 2012: 18) that creativity is an experience in expressing oneself with nature and other living things. 


\section{Method}

Researchers used quantitative methods, because the data in this study contained numbers obtained from the data and then processed using statistics and then interpreted. In accordance with Arikunto's (2010) statement that quantitative research is a method that uses numbers in interpreting data and the appearance of research results.

This approach is used because it is based on the understanding that scientific and research validity comes from the use of data that can be measured strictly, whose data is extracted through questionnaires or questionnaires and analyzed using statistics and testing research allegations that are free from subjectivity (Neuman, 2003). According to Creswell (2010: 77) the variables that may have an effect, causing the dependent variable, is the professional competence of the teacher. While the independent variables (independent variables), namely the dependent variable that the independent variableon the variables of self-concept and creativity. The research data was collected by distributing questionnaires and then the results of the questionnaires would be analyzed.

The place of this research is in PAUD in Cakranegara district, NTB. The location of this research has been previously determined to make it easier for researchers to conduct research. The population of this study were all kindergarten teachers in the Cakranegara district of NTB.The sample in this study was determinedusing a census approach.

Table 1. Respondents Answer Score

\begin{tabular}{|l|l|l|}
\hline No & \multicolumn{1}{|c|}{ Answer Respondent } & Score \\
\hline 1. & Strongly Agree (SS), Very Good (SB) & 5 \\
\hline 2. & Agree (S), Good (B) & 4 \\
\hline 3. & Doubtful (RR), Enough (C) & 3 \\
\hline 4. & Disagree (TS), Not Good (TB) & 2 \\
\hline 5. & Strongly Disagree (STS), Strongly Disagree (STB) & 1 \\
\hline
\end{tabular}

Source: Sugiyono (2012:133)

Research is a very important component in carrying out a research, because the results of the study depend on the instruments used. The instrument is a tool to measure and collect empirical data as the value of the variable under study (Iskandar, 2013). In this study, the researcher used a questionnaire instrument as a data collection tool, it was based on consideration of the research approach that used a quantitative approach.

The process of preparing the questionnaire is based on the indicators of each variable, which are then also adjusted to the target situation. The nature of the questionnaire that provides closed options so that respondents just choose the answers that have been provided by the researcher as well as several questionnaires with open options for profile information. Validity test is useful for measuring the level of validity of the questionnaire. Questionnaires can be said to be valid if the questions are able to reveal what will be measured (Ghozali, 2005). In measuring the validity, it is done by measuring the relationship between the score of each question and the total score. Testing the validity of the self-concept instrument and the creativity of the professional competence of PAUD teachers in this study utilized the SPSS version 20.0 program. Testing the validity of the instrument in this study uses construct validity testing by calculating the product moment correlation formula (Siregar, 2012: 77). An instrument is declared valid if:

\begin{tabular}{|l|l|l|l|}
\hline No & \multicolumn{1}{|c|}{ Gender } & \multicolumn{1}{|c|}{ Amount } & \multicolumn{1}{c|}{ Percentage } \\
\hline 1 & Man & 31 & $28 \%$ \\
\hline 2 & Woman & 79 & $72 \%$ \\
\hline Amount & 110 & $100 \%$ \\
\hline
\end{tabular}

Data source: Primary data processed (2021) 
Based on the table above from 110 respondents, it can be concluded that most of the PAUD teachers in Cakranegara NTB are women with a percentage of $72 \%$. Meanwhile, with female gender, $28 \%$ are female. An instrument can be said to be reliable if the instrument is used more than once by showing consistent results. The reliability of an instrument can be trusted because the instrument is good (Arikunto, 2002). Based on this opinion, reliability testing is a process in testing each question in the questionnaire.

\section{Result and Discussion}

This study shows the results of the self-concept variable (X1) have a significance value (Sig.) 0.000 in the Coefficientsa table with a value (degree of significance) 0.05 meaning $0.000<0.05$ or there is a significant effect and the t test shows $2.123>\mathrm{t}$ table $(2,000)$. Teachers as professional educators must be able to master competencies in teaching and learning activities. Competence is the mastery of abilities, skills, knowledge, and attitudes that can be seen from performance (Samani, 2006: 16). Competence can be interpreted as behavior in exploring, investigating, analyzing, digesting, and paying attention to direct someone in finding ways to achieve their goals (Mulyana, 2013: 26). So that achievement becomes a benchmark in assessing the personality of students. Students with good personalities will be realized if there are professional teachers who can fully guide them.

Muhibbin Shah (2000:299) that competence is a person's ability or skill. According to Barlow (in Daryanto, 2013:157) that competence is the ability of teachers to carry out their responsibilities appropriately. Based on the existing opinion, the conclusion is that competence is the ability of a person who has become part of him both qualitatively and quantitatively in deciding a thing. One of the factors that influence teacher competence is self-concept. Self-concept can be seen from the attitude they display. Humans have the drive to develop. Existing developments then form the self-concept within the individual, so that individuals are able to influence and improve one's competence.

Fitts (Agustiani, 2006: 139) that self-concept has an influence on a person's behavior. Knowledge in recognizing a person's self-concept can make it easier for us to understand someone's behavior. Generally, behavior is related to ideas about self-concept. The individual's behavior is related to the deficiencies he perceives.

Calhoun \&Accocella (2000:67) that self-concept becomes self-view. This view is a mental process consisting of 3 dimensions, namely knowledge, expectations, and selfassessment. Hurlock $(2004: 237)$ that self-concept is a person's view of himself. This concept consists of two components, namely the ideal concept is a picture that the individual wants while the self-concept is actually a depiction of the individual's reality. Then the self-concept is the attitude of an individual in understanding the behavior of someone who has knowledge, expectations and judgments about himself can develop into a positive or negative. Teaching is a profession that is highly respected by society. Because teachers are tasked with educating the nation's next generation towards quality human resources (Usman 2016:7). Teachers are not only tasked with delivering learning materials in formal education classes. But also carry out the mandate in educating students to have broad knowledge and noble character. To carry out this mandate, teachers must have high creativity (Khurohman, 2017).

\section{Conclusion}

Based on the results of research and discussion, the conclusions in the study are as follows:

1. The results showed that there was a significant positive effect of self-concept on the professional competence of PAUD teachers in Cakranegara District, NTB. 
2. The results showed that there was a significant positive effect of creativity on the professional competence of PAUD teachers in Cakranegara District, NTB.

3. The results showed that there was a simultaneous influence between self-concept and creativity on the professional competence of PAUD teachers in Cakranegara District, NTB.

\section{References}

Agustiani, H. 2006. Psikologi Perkembangan (Pendekatan Ekologi kaitannya dengan Konsep Diri dan Penyesuaian Diri Pada Remaja). Bandung: Rafika Aditama.

Anoraga, Panji. 2009. Psikologi Kerja. Jakarta: Rineka Cipta.

Arikunto, S. 2006. Prosedur Penelitian: Suatu Pendekatan Praktik. Cetakan ke-14. Jakarta: PT Rineka Cipta.

Azis. 2014. Hubungan Antara Motivasi Kerja Guru dan Konse Diri Guru dengan Kompetensi Guru Madrasah Ibtidaiyah Negeri (MIN) Se Kecamatan Kalijambe Kabupaten Sragen. Tesis. Surakarta.

Bungin, B., H., M. 2013. Metodologi Penelitian Sosial \& Ekonomi: Format-Format Kuantitatif dan Kualitaif untuk Sstudi Sosiologi, Kebijakan Publik, Komunikasi, manejemen, dan Pemasaran. Cetakan Pertama. Jakarta. Prenadamedia Group.

Calhoun, J.F., Acocella, J.R. 2000. Psikologi tentang Penyesuaian dan Hubungan Kemanusiaan. Alih bahasa: Satmoko. Semarang: IKIP Semarang Press.

Creswell, W. John. 2010. Research Design Pendekatan Kualitatif, Kuantitatif, Dengan Mixed. Cetakan 1. Yogyakarta. Pustaka Pelajar.

Dayakisni \& Hudaniyah. 2003. Psikologi Sosial edisi rivisi. Malang: UMM Press.

Ernawulan Syaodih. 2005. Bimbingan di Taman Kanak-Kanak. Jakarta: Depdinas Ditjet Dikti Pembinaan pendidikan Tenaga Kependidikan dan Ketenagaan Perguruan Tinggi.

FX Sudarsono. 1989. Beberapa Prinsip dalam Penelitian. Yogyakarta: Bimbingan Penelitian Karya Ilmiah SEMA FIP IKIP Yogyakarta.

Hendra, Indy H dan Handoyo Seregar. 2013. Hubungan Kepuasan Kerja dengan Motivasi Kerja Pada Karyawan Bnak BTPN Madiun. Jurnal Psikologi Industri dan Organisasi. Madiun.

Hurlock, E. B. 2004. Psikologi Perkembangan; Suatu Pendekatan Sepanjang Rentang Kehidupan. Alih bahasa: Istiwidayanti \& Sijabat, Max R. Jakarta: Penerbit Erlangga.

Ida Windi Wahyuni, Alucyana dan Dian Tri Utami. 2020. Pengaruh Konsep Diri, Masa Kerja dan Latar Belakang Pendidikan Terhadap Motivasi Kerja Kepala RA. Al Hikmah: Indonesian of Early Childhood Islamic Education. Riau.

Irmin \& Rochim. 2006. Menjadi Guru yang Bisa Digugu dan Ditiru. Surabaya: Setya Media. 
Iskandar. 2013. Metodologi Penelitian Pendidikan dan Sosial. Jakarta: Referensi.

Ismail, F. 2018. Manajemen Berbasis Sekolah: Solusi Peningkatan Kualitas Pendidikan. Jurnal Ilmiah Iqra, 2(2), 1-17.

Jalaludin Rakhmat. 2001. Psikologi Komunikasi. Bandung: PT. Remaja Rosdakarya.

Kambey, D. C. 2010. Manajemen Sumber Daya Manusia. Manado: Yayasan Triganesha Nusantara.

Khurohmah, M. 2017. Hubungan Kreativitas Guru dan Motivasi Belajar Dengan Hasil Belajar Siswa Kelas IV SDN Gugur Cut Nyak Dien Kabupaten Rembang. Skripsi Pendidikan. Semarang.

Martini Jamaris. 2006. Proses Kreativitas Anak. Jakarta: Erlangga.

Masanah. 2019. Pengaruh Budaya Organisasi Dan Motivasi Berprestasi Terhadap Kompetensi Profesional Guru Sekolah Dasar Negeri Di Kecamatan Bonang Kabupaten Demak. Thesis Pendidikan.

Masitoh dkk. 2005. Pendekatan Belajar Aktif di Taman Kanak-Kanak. Jakarta: Depdinas Ditjet Dikti Pembinaan pendidikan Tenaga Kependidikan dan Ketenagaan Perguruan Tinggi.

Masyhud, M., S. 2014. Metode Penelitian Pendidikan Penuntun Ragam Penelitian. Edisi 4. Jember. Lembaga Pengembang Manajemen dan Profesi Kependidikan.

Moeslichantoen. 2004. Metod Pengajaran di Taman Kanak-Kanak. Jakarta: Rineka Cipta.

Muchlas Samani. 2006. Mengenal Sertifikasi Guru di Indonesia. Jakarta: Asosiasi Peneliti Pendidikan Indonesia

Hurlock, E. B. 2004. Psikologi Perkembangan; Suatu Pendekatan Sepanjang Rentang Kehidupan. Alih bahasa: Istiwidayanti \& Sijabat, Max R. Jakarta: Penerbit Erlangga.

Ida Windi Wahyuni, Alucyana dan Dian Tri Utami. 2020. Pengaruh Konsep Diri, Masa Kerja dan Latar Belakang Pendidikan Terhadap Motivasi Kerja Kepala RA. Al Hikmah: Indonesian of Early Childhood Islamic Education. Riau.

Irmin \& Rochim. 2006. Menjadi Guru yang Bisa Digugu dan Ditiru. Surabaya: Setya Media.

Iskandar. 2013. Metodologi Penelitian Pendidikan dan Sosial. Jakarta: Referensi.

Ismail, F. 2018. Manajemen Berbasis Sekolah: Solusi Peningkatan Kualitas Pendidikan. Jurnal Ilmiah Iqra, 2(2), 1-17.

Jalaludin Rakhmat. 2001. Psikologi Komunikasi. Bandung: PT. Remaja Rosdakarya.

Kambey, D. C. 2010. Manajemen Sumber Daya Manusia. Manado: Yayasan Triganesha Nusantara.

Khurohmah, M. 2017. Hubungan Kreativitas Guru dan Motivasi Belajar Dengan Hasil Belajar Siswa Kelas IV SDN Gugur Cut Nyak Dien Kabupaten Rembang. Skripsi Pendidikan. Semarang.

Martini Jamaris. 2006. Proses Kreativitas Anak. Jakarta: Erlangga.

Masanah. 2019. Pengaruh Budaya Organisasi Dan Motivasi Berprestasi Terhadap Kompetensi Profesional Guru Sekolah Dasar Negeri Di Kecamatan Bonang Kabupaten Demak. Thesis Pendidikan.

Masitoh dkk. 2005. Pendekatan Belajar Aktif di Taman Kanak-Kanak. Jakarta: Depdinas Ditjet Dikti Pembinaan pendidikan Tenaga Kependidikan dan Ketenagaan Perguruan Tinggi.

Masyhud, M., S. 2014. Metode Penelitian Pendidikan Penuntun Ragam Penelitian. Edisi 4. Jember. Lembaga Pengembang Manajemen dan Profesi Kependidikan.

Moeslichantoen. 2004. Metod Pengajaran di Taman Kanak-Kanak. Jakarta: Rineka Cipta.

Muchlas Samani. 2006. Mengenal Sertifikasi Guru di Indonesia. Jakarta: Asosiasi Peneliti Pendidikan Indonesia.

Mulyanto, A. S. 2008. Hubungan Antara Kompetensi Profesional Guru Dan Konsep Diri Guru Dengan Kinerja Guru Kelas V Sekolah Dasar Negeri Di Kecamatan Grogol Kabupaten Sukoharjo Tahun 2008/2009 (Doctoral dissertation, Tesis tidak dipublikasikan Program Studi Teknologi Pendidikan Program Pascasarjana Universitas Sebelas Maret. Surakarta)

Mulyasa, E. 2012. Manajemen dan Kepemimpinan Kepala Sekolah. Jakarta: Bumi Aksara.

Mulyasa, E. 2007. Standar Kompetensi dan Sertifikasi Guru. Bandung: Rosda Karya.

Munandar, S.C.U. 2009. Pengembangan Kreativitas Anak Berbakat. Jakarta: PT Rineka Cipta dan Dep. Pendidikan dan Kebudayaan.

Naim, Ngainun. 2013. Menjadi Guru Inspiratif. Yogyakarta: Pustaka Pelajar

Ngalim Purwanto. 2007. Psikologi Pendidikan. Bandung: Remaja Rosdakarya.

Notoatmodjo 2005. Metodologi Penelitian. Jakarta. Rineka Cipta. 
Nurkolis. 2005. Manajemen Berbasis Sekolah. Jakarta: Grasindo.

Nursisto. 2000. Kiat Menggali Kreativitas. Yogyakarta: Mitra Gama Widya.

Oemar, H. 2002. Perencanaan Pengajaram Berdasarkan Sistem: Cet ke I. Jakarta: Bumi Aksara.

Peraturan Menteri Pendidikan Nasional Indonesia Nomor 16 Tahun 2007 Tentang Standar Kualifikasi Akademik Dan Standar Kompetensi Guru, Standar Kompetensi Kepala Sekolah, Standar Kompetensi Pengawas (Permendiknas No. 12, 13, dan 16).

Permendiknas No.16 Tahun 2007 tentang Standar. Kualifikasi Akademik dan Kompetensi Guru. Jakarta: Seketariat Negara.

Rahmat, J. 2007. Psikologi Komunikasi. Bandung: Remaja Rosdakarya.

Rasyid H. 2009. Asesmen Perkembangan Anak Usia Dini. Yogyakarta: Multi Pressindo.

Rusneli. 2016. Pengaruh Kepemimpinan Kepala Sekolah Disiplin Kerja Dan Konsep Diri Terhadap Kompetensi Profesional Guru. Jurnal Tesis Pendidikan.

Sangadji, E., M. \& Sopiah. 2010. Metode Penelitian: Pendekatan Praktis dalam Peneliian. Yogyakarta. Penerbit ANDI.

Sardiman. 2014. Interaksi dan Motivasi Belajar Mengajar. Jakarta: Raja Grafindo Persada.

Senjaya, W. 2013. Penelitian Pendidikan Jenis, Metode, dan Prosedur. Jakarta. Edisi Pertama. Cetakan Ke-2. Kencana Media Group.

Slameto. 2003. Belajar dan Faktor-Faktor yang Mempengaruhinya. Jakarta: Rineka Cipta.

Sri Judiani, "Kreativitas dan Kompetensi Guru Sekolah Dasar", Pendidikan dan Kebudayaan, Vol. 17 No. 1,58 .

Sugiyono. 2015. Statistika untuk penelitian. Bandung: Alfabeta.

Suyadi Prawirosentono. 2008. Manajemen Sumber Daya Manusia Kebijakan Kinerja Karyawan Kiat Membangun Organisasi Kompetitif Era Perdagangan Bebas Dunia. Edisi kedua. Yogyakarta: BPFE.

Suyanto, S. 2005. Dasar-Dasar Pendidikan Anak Usia Dini. Yogyakarta: Hikayat

Tabrani Rusyan dkk. 2000. Upaya Meningkatkan Budaya Kinerja Guru. Cianjur: CV.

Universitas Negeri Malang. 2017. Pedoman Penulisan Karya Ilmiah: Skripsi, Tesis, Disertasi, Artikel, Makalah, Tugas Akhir, Laporan Penelitian. Edisi keenam. Malang. Universitas Negeri Malang.

Uno, hamzah B. 2010. Teori Motivasi dan Pengukurannya; Analisis DI Bidang Pendidikan. Jakarta: Bumi Aksara.

Usman, U. 2016. Menjadi Guru Profesional. Bandung: PT Remaja Rosdaakarya.

Vetti Priskilla Wadani. 2013. Pengaruh Kinerja Guru Terhadap Motivasi Belajar Anak Kelompok B Sekolah Taman Kanak-Kanak Dharma Wanita Se Kecamatan Kedu Kabupaten Temanggung. Skripsi Pendidikan. Yogyakarta. 